\title{
Mechanical and Magnetic Properties of New (Fe,Co,Ni)-B-Si-Ta Bulk Glassy Alloys
}

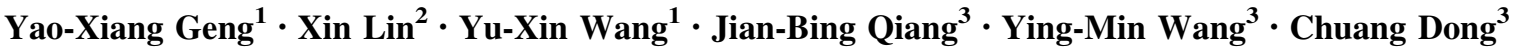

Received: 13 January 2017/Revised: 20 March 2017/Published online: 5 April 2017

(C) The Chinese Society for Metals and Springer-Verlag Berlin Heidelberg 2017

\begin{abstract}
The alloying effects of the like-atom substitution of $\mathrm{Ni}$ and $\mathrm{Co}$ for $\mathrm{Fe}$ on the various properties of $\mathrm{Fe}_{70} \mathrm{~B}_{16.7}$ $\mathrm{Si}_{8.3} \mathrm{Ta}_{5}$ metallic glass are investigated in this present work. New Fe-based bulk glassy alloys, namely $\mathrm{Fe}_{60-x} \mathrm{Co}_{x} \mathrm{Ni}_{10-}$ $\mathrm{B}_{16.7} \mathrm{Si}_{8.3} \mathrm{Ta}_{5}$ (at.\%; $x=10,20$ and 30 ) with critical diameters up to $1.5 \mathrm{~mm}$, were made by means of copper mold casting. A new glass-forming ability indicator, viz., the enthalpy of supercooled liquid, has been introduced for assessment of the glass-forming abilities (GFAs) of these Fe-based multi-component alloys. Nano-indentation results indicate that the calculated elastic modulus and hardness of the bulk glassy alloys are lower than those of the $\mathrm{Fe}_{70} \mathrm{~B}_{16.7} \mathrm{Si}_{8.3} \mathrm{Ta}_{5}$ alloy. Among these bulk glassy alloys, $\mathrm{Fe}_{70} \mathrm{~B}_{16.7} \mathrm{Si}_{8.3} \mathrm{Ta}_{5}$ exhibits the large elastic modulus and hardness with values of $178 \pm 1$ $\mathrm{GPa}$ and $12.9 \pm 0.1 \mathrm{GPa}$, respectively. All the bulk glassy alloys exhibit good soft magnetic properties with high saturation magnetization $B_{\mathrm{s}} \sim 0.75-1.04 \mathrm{~T}$ but low coercive force $H_{\mathrm{c}} \sim 0.2-5.2 \mathrm{~A} / \mathrm{m}$.
\end{abstract}

\section{KEY WORDS: (Fe, Co, Ni)-B-Si-Ta bulk glass alloys; Glass-forming ability; Mechanical property; Magnetic property}

\section{Introduction}

Fe-based amorphous alloys are known to have attractive soft magnetic properties including high saturation magnetization $\left(B_{\mathrm{s}}\right)$, low coercive force $\left(H_{\mathrm{c}}\right)$, low core loss and

Available online at http://link.springer.com/journal/40195.

Yao-Xiang Geng

1027431200@qq.com

Ying-Min Wang

apwangym@dlut.edu.cn

1 School of Materials Science and Engineering, Jiangsu University of Science and Technology, Zhenjiang 212003, China

2 State Key Laboratory of Solidification Processing, Northwestern Polytechnical University, Xi' an 710072, China

3 Key Laboratory of Materials Modification (Ministry of Education), Dalian University of Technology, Dalian 116024, China high magnetic permeability $(\mu)$ [1-3]. Indeed, this has led to their use in a wide variety of industrial applications especially in transformer cores and magnetic sensors [4]. However, their sizes are limited due to the rapid liquid cooling required for retention of amorphous structure, and this restricts their applications in some areas. There has been continued interest in the enhanced glass-forming ability (GFA) of Fe-based amorphous alloys to exploit excellent soft magnetic properties. Following the first discovery of $\mathrm{Fe}-(\mathrm{Al}, \mathrm{Ga})-\mathrm{P}-\mathrm{C}-\mathrm{B}$ bulk glassy alloys, various Fe-based bulk metallic glasses (BMGs) have been developed in many different multi-component alloy systems [5, 6]. Among them, the Fe-B-Si-ETM (Early Transition Metals, ETM $=\mathrm{Nb}, \mathrm{Zr}$, Hf and Ta) quaternary bulk glassy alloys exhibit large GFA (the critical diameter for glass formation $d_{\mathrm{c}} \geq 2.5 \mathrm{~mm}$ ), high fracture strength $\left(\sigma_{\mathrm{f}} \sim 4000 \mathrm{MPa}\right)$ and good soft magnetic properties $\left(B_{\mathrm{s}} \sim 1.13-1.51 \mathrm{~T}\right.$ and $\left.H_{\mathrm{c}} \sim 1.5-6.7 \mathrm{~A} / \mathrm{m}\right)$ [7-11]. In particular, magnetic powder cores named "SENNTIX-I," which are made of $\mathrm{Fe}-\mathrm{B}-\mathrm{Si}-\mathrm{Nb}$ glassy alloys, have found 
to be practical use in the choke coils of AC-DC and DCDC converters [6]. In the studies of Fe-based BMGs, likeatom-substitution has demonstrated an effective alloying strategy to reach large GFA and the improved mechanical and magnetic properties. For instance in the $\mathrm{Fe}-\mathrm{B}-\mathrm{Si}-\mathrm{Nb}$ system, the replacement of $\mathrm{Fe}$ by $\mathrm{Co}$ has resulted in not only the improved GFA and mechanical properties [9, 12], but also the increases of $B_{\mathrm{s}}$ and the Curie temperature $\left(T_{\mathrm{c}}\right)$ $[13,14]$, and the former property improvements being mainly attributed to the greater negative mixing enthalpy of $\mathrm{Co}-\mathrm{Nb}$ atomic pair than that of $\mathrm{Fe}-\mathrm{Nb}$, and the latter to the strong exchange coupling between $\mathrm{Fe}$ and $\mathrm{Co}$.

The cluster-plus-glue-atom model has been successfully used for understanding and designing alloy compositions with large GFA in many systems [15]. In our previous work, a series of $\left[\mathrm{Si}-\mathrm{B}_{2} \mathrm{Fe}_{8-x} \mathrm{Ta}_{x}\right] \mathrm{Fe}$ bulk glassy alloys with $d_{\mathrm{c}}=1.0 \mathrm{~mm}$ were designed by using this model, and these BMGs exhibit good soft magnetic and mechanical properties, where in the cluster formula expression the center and the first neighbor atoms are separated by a hyphen, the cluster is enclosed in the square brackets and the glue atom locates outside the square brackets [10]. In the present work, the variations of the mechanical and soft magnetic properties of $\mathrm{Fe}_{70} \mathrm{~B}_{16.7} \mathrm{Si}_{8.3} \mathrm{Ta}_{5}$ and $\mathrm{Fe}_{60-x} \mathrm{Co}_{x-}$ $\mathrm{Ni}_{10} \mathrm{~B}_{16.7} \mathrm{Si}_{8.3} \mathrm{Ta}_{5}(x=0,10,20$ and 30$)$ bulk glassy alloys have been investigated. In addition, a new GFA indicator, enthalpy of supercooled liquid $\left(\Delta H_{\text {sup }}\right)$, was proposed for these BMG-forming alloys.

\section{Experimental}

Alloy ingots with the desired compositions of $\mathrm{Fe}_{70} \mathrm{~B}_{16.7-}$ $\mathrm{Si}_{8.3} \mathrm{Ta}_{5}$ and $\mathrm{Fe}_{60-x} \mathrm{Co}_{x} \mathrm{Ni}_{10} \mathrm{~B}_{16.7} \mathrm{Si}_{8.3} \mathrm{Ta}_{5}$ (at.\%; $x=0,10$, 20 and 30) were prepared by arc melting under argon atmosphere. The purities of raw materials are 99.999 mass \% for $\mathrm{Fe}$ and $\mathrm{Si}, 99.95$ mass\% for Ta and 99.5 mass\% for B, respectively. Alloy rods with different diameters were prepared by copper mold suction casting. For melt spinning, the surface speed of the copper wheel was set to $40 \mathrm{~m} / \mathrm{s}$. The dimensions of ribbon samples were approximately $1.5 \mathrm{~mm}$ in width and $20-30 \mu \mathrm{m}$ in thickness. The structures of as-prepared ribbon and rod samples were examined by a Bruker D8 Focus X-ray diffractometer (XRD, $\mathrm{Cu}-K_{\alpha}$ radiation, $\lambda=0.15406 \mathrm{~nm}$ ). The thermal glass properties of the as-prepared alloys, such as the glass transition temperature $\left(T_{\mathrm{g}}\right)$, the crystallization temperature $\left(T_{x}\right)$, the melting temperature $\left(T_{\mathrm{m}}\right)$, and the liquidus temperature $\left(T_{1}\right)$, were measured by Differential Scanning Calorimetry (DSC) and Differential Thermal Analysis (DTA) at a heating rate of $0.67 \mathrm{~K} / \mathrm{s}$. The magnetic properties, such as $B_{\mathrm{s}}$ and $H_{\mathrm{c}}$, were measured with a MATS2010SD Hysteresis-graph. Nano-indentation experiments on the $1.0 \mathrm{~mm}$ diameter glassy alloy rods were carried out by using a CSM nano-indenter at a constant strain rate of $0.05 \mathrm{~s}^{-1}$ and under a maximum load of $200 \mathrm{mN}$. The hardness and modulus of samples were calculated by using the method proposed by Oliver and Pharr [16]. The Vickers hardness $\left(H_{\mathrm{v}}\right)$ measurement was conducted on the $1.0 \mathrm{~mm}$ diameter rod samples under a load of $500 \mathrm{~g}$. Five times for each of the specimens were carried out in mechanical properties testing. The morphology of the Vicker's hardness indentations was observed by optical microscopy (OM).

\section{Results and Discussions}

The X-ray diffraction patterns of $\mathrm{Fe}_{70} \mathrm{~B}_{16.7} \mathrm{Si}_{8.3} \mathrm{Ta}_{5}$ and $\mathrm{Fe}_{60-x} \mathrm{Co}_{x} \mathrm{Ni}_{10} \mathrm{~B}_{16.7} \mathrm{Si}_{8.3} \mathrm{Ta}_{5}(x=0,10,20$ and 30) meltspun samples are presented in Fig. 1a. All the samples show a typical amorphous structure. The $d_{\mathrm{c}}$ values of different bulk samples are presented in Fig. $1 \mathrm{~b}$ along with their diffraction patterns. Glassy alloy rods were produced at all compositions under investigation, viz., $d_{\mathrm{c}} \sim 1.0 \mathrm{~mm}$ for $\mathrm{Fe}_{70} \mathrm{~B}_{16.7} \mathrm{Si}_{8.3} \mathrm{Ta}_{5}$ and $\mathrm{Fe}_{60} \mathrm{Ni}_{10} \mathrm{~B}_{16.7} \mathrm{Si}_{8.3} \mathrm{Ta}_{5}$ and $d_{\mathrm{c}} \sim 1.5 \mathrm{~mm}$ for $\mathrm{Fe}_{50} \mathrm{Co}_{10} \mathrm{Ni}_{10} \mathrm{~B}_{16.7} \mathrm{Si}_{8.3} \mathrm{Ta}_{5}, \mathrm{Fe}_{40} \mathrm{Co}_{20}$ $\mathrm{Ni}_{10} \mathrm{~B}_{16.7} \mathrm{Si}_{8.3} \mathrm{Ta}_{5}$ and $\mathrm{Fe}_{30} \mathrm{Co}_{30} \mathrm{Ni}_{10} \mathrm{~B}_{16.7} \mathrm{Si}_{8.3} \mathrm{Ta}_{5}$, respectively. The casting experiment indicates that substitution of Co for Fe results in the enhanced GFA in the present system. When the rod diameter of the casting samples exceeds the $d_{\mathrm{c}}$, partially crystallization of the $\mathrm{Fe}_{23} \mathrm{~B}_{6}, \mathrm{Fe}_{2} \mathrm{~B}$ and bcc-Fe-type phases occurs (Fig. 1c). These results are similar to the previously reported in $(\mathrm{Fe}, \mathrm{Co}, \mathrm{Ni})-\mathrm{B}-\mathrm{Si}-\mathrm{Nb}$ alloys [17, 18].

Figure 2a shows the DSC curves of $\mathrm{Fe}_{70} \mathrm{~B}_{16.7} \mathrm{Si}_{8.3} \mathrm{Ta}_{5}$ and $\mathrm{Fe}_{60-x} \mathrm{Co}_{x} \mathrm{Ni}_{10} \mathrm{~B}_{16.7} \mathrm{Si}_{8.3} \mathrm{Ta}_{5}(x=0,10,20$ and 30) glassy alloys made by melt spinning. It is seen that glass transition becomes distinct in the samples with the addition of $\mathrm{Ni}$ and with increasing Co content. The thermal glass stability parameters of $T_{\mathrm{g}}, T_{x}$, the supercooled liquid region spans of $\Delta T_{x}=T_{x}-T_{\mathrm{g}}, T_{\mathrm{m}}$ and $T_{1}$ are obtained from the DSC and DTA (Fig. 2b) curves, and these are summarized in Table 1. It was found that the $T_{\mathrm{g}}$ and $T_{x}$ of glassy alloys decreased from $858 \mathrm{~K}$ and $889 \mathrm{~K}$ to $845 \mathrm{~K}$ and $881 \mathrm{~K}$, respectively, with the addition of $\mathrm{Ni}$, and then increased with increasing Co content. Subtle changes are found for the $\Delta T_{x}$ values of these BMG alloys, whereas $T_{\mathrm{m}}$ and $T_{1}$ of them decrease rapidly due to the presences of $\mathrm{Ni}$ and $\mathrm{Co}$. The reduced glass transition temperature, $T_{\mathrm{rg}}=T_{\mathrm{g}} / T_{1}$, was calculated to assess the GFAs of these alloys. The variation of $T_{\mathrm{rg}}$ against alloy composition is plotted in Fig. 3. It can be seen that $T_{\mathrm{rg}}$ increases with increasing Co content and the largest value of $T_{\mathrm{rg}}=0.618$ is reached at $\mathrm{Fe}_{30} \mathrm{Ni}_{10}$ $\mathrm{Co}_{30} \mathrm{~B}_{16.7} \mathrm{Si}_{8.3} \mathrm{Ta}_{5}$. The varied GFA as predicted by the $T_{\mathrm{rg}}$ values is consistent with the results of critical glass 

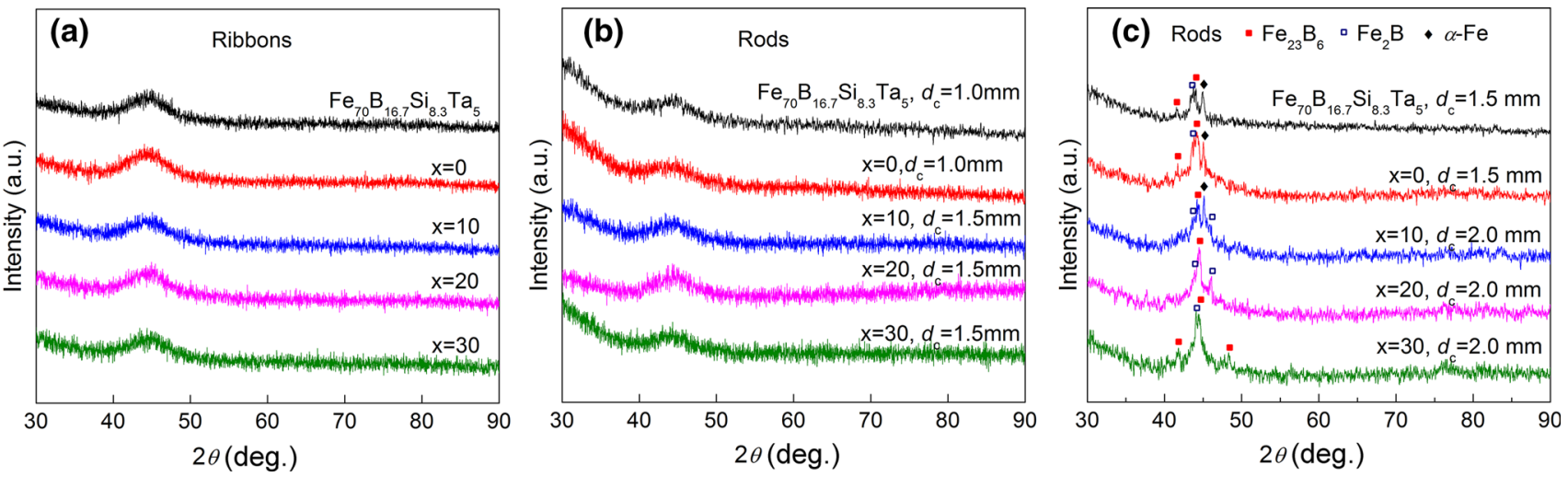

Fig. $1 \mathrm{X}$-ray diffraction patterns of the melt-spun ribbons $\mathbf{a}$, as-cast rods with the critical diameters $\mathbf{b}$ and the rod samples with a diameter larger than the critical value $\mathbf{c}$ of $\mathrm{Fe}_{70} \mathrm{~B}_{16.7} \mathrm{Si}_{8.3} \mathrm{Ta}_{5}$ and $\mathrm{Fe}_{60-x} \mathrm{Co}_{x} \mathrm{Ni}_{10} \mathrm{~B}_{16.7} \mathrm{Si}_{8.3} \mathrm{Ta}_{5}(x=0,10,20$ and 30) alloys
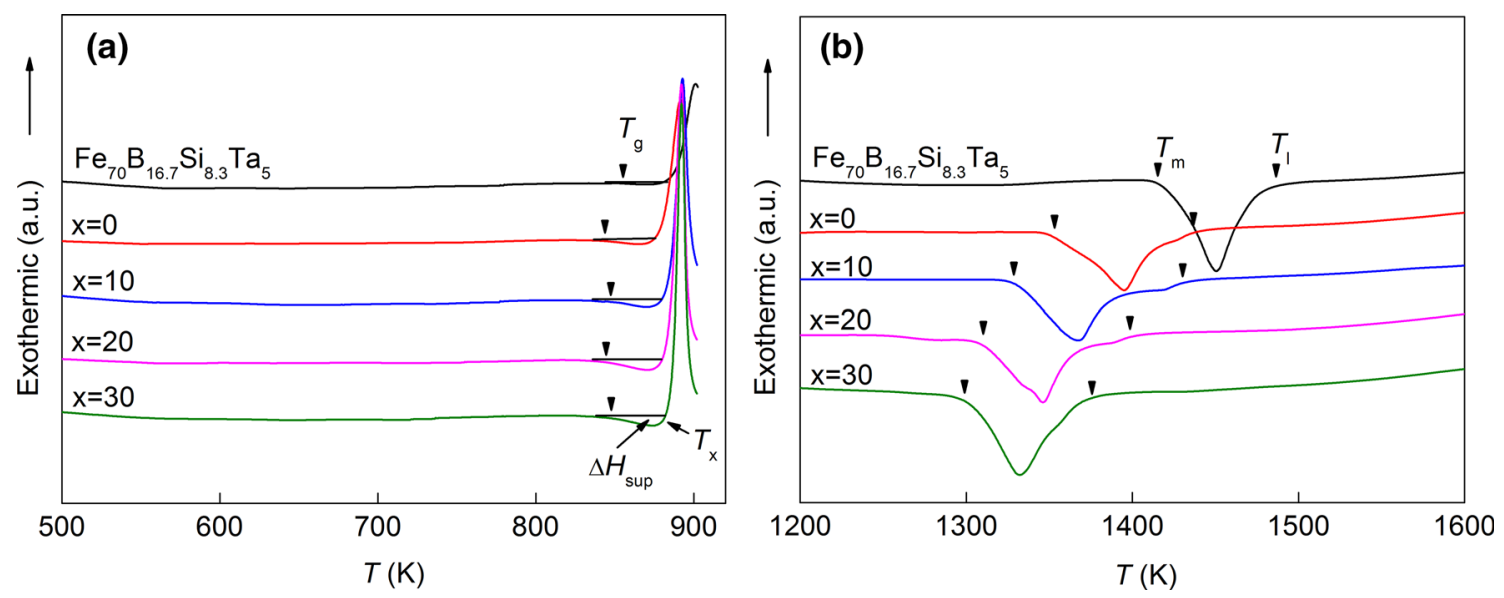

Fig. 2 DSC a and DTA $\mathbf{b}$ curves of $\mathrm{Fe}_{70} \mathrm{~B}_{16.7} \mathrm{Si}_{8.3} \mathrm{Ta}_{5}$ and $\mathrm{Fe}_{60-x} \mathrm{Co}_{x} \mathrm{Ni}_{10} \mathrm{~B}_{16.7} \mathrm{Si}_{8.3} \mathrm{Ta}_{5}(x=0,10,20$ and 30) glassy alloys

Table 1 Thermal, mechanical and soft magnetic properties of $\mathrm{Fe}_{70} \mathrm{~B}_{16.7} \mathrm{Si}_{8.3} \mathrm{Ta}_{5}$ and $\mathrm{Fe}_{60-x} \mathrm{Co}_{x} \mathrm{Ni}_{10} \mathrm{~B}_{16.7} \mathrm{Si}_{8.3} \mathrm{Ta}_{5}$ glassy alloys

\begin{tabular}{llllllllllllll}
\hline Compositions & $x$ & $\begin{array}{l}d_{\mathrm{c}} \\
(\mathrm{mm})\end{array}$ & $\begin{array}{l}T_{\mathrm{g}} \\
(\mathrm{K})\end{array}$ & $\begin{array}{l}T_{x} \\
(\mathrm{~K})\end{array}$ & $\begin{array}{l}\Delta T_{x} \\
(\mathrm{~K})\end{array}$ & $\begin{array}{l}\Delta H_{\text {sup }} \\
(\mathrm{J} / \mathrm{g})\end{array}$ & $\begin{array}{l}T_{1} \\
(\mathrm{~K})\end{array}$ & $T_{\mathrm{rg}}$ & $H_{\mathrm{v}}(\mathrm{GPa})$ & $H_{\mathrm{N}}(\mathrm{GPa})$ & $\begin{array}{c}E(\mathrm{GPa}) \\
\mathrm{B}_{\mathrm{s}} \\
(\mathrm{T})\end{array}$ & $\begin{array}{l}H_{\mathrm{c}} \\
(\mathrm{A} / \mathrm{m})\end{array}$ \\
\hline $\mathrm{Fe}_{70} \mathrm{Ta}_{5} \mathrm{~B}_{16.67} \mathrm{Si}_{8.33}$ & - & 1.0 & 858 & 889 & 31 & 0.7 & 1479 & 0.580 & $11.1 \pm 0.2$ & $12.9 \pm 0.1$ & $178 \pm 1$ & 1.02 & 1.0 \\
$\mathrm{Fe}_{60} \mathrm{Ni}_{10} \mathrm{Ta}_{5} \mathrm{~B}_{16.67} \mathrm{Si}_{8.33}$ & 0 & 1.0 & 845 & 881 & 36 & 2.6 & 1438 & 0.588 & $10.7 \pm 0.1$ & $11.5 \pm 0.3$ & $163 \pm 1$ & 1.04 & 0.2 \\
$\mathrm{Fe}_{50} \mathrm{Co}_{10} \mathrm{Ni}_{10} \mathrm{Ta}_{5} \mathrm{~B}_{16.67} \mathrm{Si}_{8.33}$ & 10 & 1.5 & 850 & 885 & 35 & 4.6 & 1434 & 0.593 & $10.8 \pm 0.3$ & $12.1 \pm 0.1$ & $158 \pm 1$ & 0.93 & 1.1 \\
$\mathrm{Fe}_{40} \mathrm{Co}_{20} \mathrm{Ni}_{10} \mathrm{Ta}_{5} \mathrm{~B}_{16.67} \mathrm{Si}_{8.33}$ & 20 & 1.5 & 845 & 885 & 40 & 7.1 & 1405 & 0.601 & $10.9 \pm 0.1$ & $11.3 \pm 0.4$ & $144 \pm 3$ & 0.83 & 2.3 \\
$\mathrm{Fe}_{30} \mathrm{Co}_{30} \mathrm{Ni}_{10} \mathrm{Ta}_{5} \mathrm{~B}_{16.67} \mathrm{Si}_{8.33}$ & 30 & 1.5 & 849 & 886 & 37 & 8.2 & 1373 & 0.618 & $11.0 \pm 0.2$ & $12.7 \pm 0.3$ & $159 \pm 3$ & 0.75 & 5.2 \\
\hline
\end{tabular}

formation size. The area of endothermic peak, namely the enthalpy of supercooled liquid $\left(\Delta H_{\text {sup }}\right)$, has been considered to characterize the stability of supercooled glassforming liquids instead of $\Delta T_{x}[19,20]$. The $\Delta H_{\text {sup }}$ exhibits the lowest value of $0.7 \mathrm{~J} / \mathrm{g}$ in the $\mathrm{Ni}$ - and Co-free alloys but increases rapidly to a greater value of $8.2 \mathrm{~J} / \mathrm{g}$ at the alloy composition with $x=30$ (Table 1 and Fig. 3). The variation tendency of $\Delta H_{\text {sup }}$ is consistent with the $d_{\mathrm{c}}$ and $T_{\mathrm{rg}}$ assessments on GFA. Therewith, $\Delta H_{\text {sup }}$ rather than $\Delta T_{x}$ is suitable for evaluating the GFA of (Fe,Ni,Co)-B-Si-Ta alloys. As shown in Fig. 3, this proposition finds further support in the $(\mathrm{Co}, \mathrm{Fe})-\mathrm{B}-\mathrm{Si}-\mathrm{Nb}$ and other bulk glassy alloys derived from like-atom substitution alloying [19, 21-24].

The mechanical properties of $\mathrm{Fe}_{70} \mathrm{~B}_{16.7} \mathrm{Si}_{8.3} \mathrm{Ta}_{5}$ and $\mathrm{Fe}_{60}$ ${ }_{x} \mathrm{Co}_{x} \mathrm{Ni}_{10} \mathrm{~B}_{16.7} \mathrm{Si}_{8.3} \mathrm{Ta}_{5}$ bulk glassy alloys were measured by means of nano-indentation. The averaged load-displacement $(P-h)$ curves of nano-indentations for these glassy alloys are 

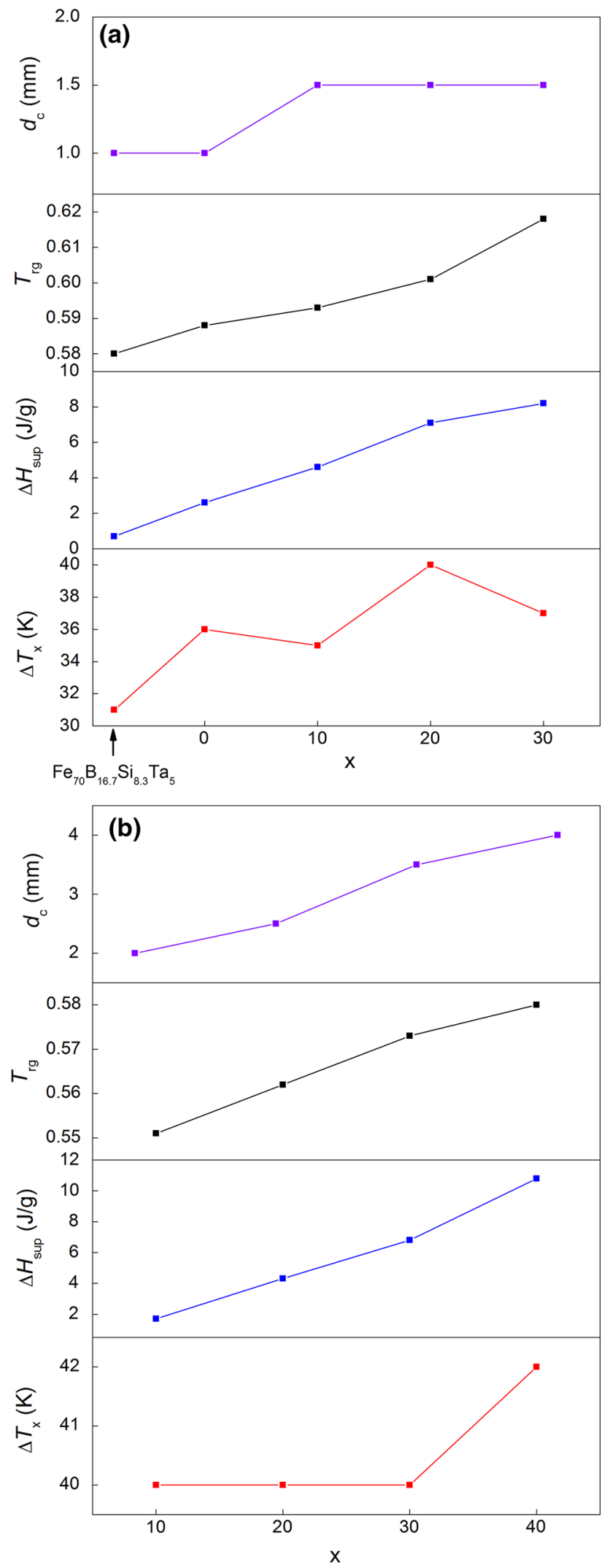

Fig. 3 Variations of $d_{\mathrm{c}}, T_{\mathrm{rg}}, \Delta H_{\text {sup }}$ and $\Delta T_{x}$ against $x$ in $\mathrm{Fe}_{60-x} \mathrm{Co}_{x-}$ $\mathrm{Ni}_{10} \mathrm{~B}_{16.7} \mathrm{Si}_{8.3} \mathrm{Ta}_{5}$ a and $\left[\left(\mathrm{Co}_{1-x} \mathrm{Fe}_{x}\right)_{0.75} \mathrm{~B}_{0.2} \mathrm{Si}_{0.05}\right]_{96} \mathrm{Nb}_{4}$ b glassy alloys presented in Fig. 4. Under the same load, the indentation depth of $\mathrm{Fe}_{70} \mathrm{~B}_{16.7} \mathrm{Si}_{8.3} \mathrm{Ta}_{5}$ glassy alloys is smaller than those produced in other samples. The $\mathrm{Fe}_{70} \mathrm{~B}_{16.7} \mathrm{Si}_{8.3} \mathrm{Ta}_{5}$ glassy alloy exhibits the highest nano-indentation hardness $\left(H_{\mathrm{N}}\right)[25,26]$. The calculated $H_{\mathrm{N}}$ and elastic modulus $(E)$ are presented in Table 1 . The values of $H_{\mathrm{N}}$ and $E$ are decreased in the glassy alloys containing $\mathrm{Ni}$ and $\mathrm{Co}$, in which the maxima of $H_{\mathrm{N}}$ and $E(12.9 \pm 0.1 \mathrm{GPa}$ and $178 \pm 1 \mathrm{GPa})$ are found in the $\mathrm{Fe}_{70}$ $\mathrm{B}_{16.7} \mathrm{Si}_{8.3} \mathrm{Ta}_{5}$ bulk glassy alloy.

The compositional dependence of the Vicker's microhardness $\left(H_{\mathrm{v}}\right)$ of $\mathrm{Fe}_{70} \mathrm{~B}_{16.7} \mathrm{Si}_{8.3} \mathrm{Ta}_{5}$ and $\mathrm{Fe}_{60-\mathrm{x}} \mathrm{Co}_{\mathrm{x}} \mathrm{Ni}_{10-}$ $\mathrm{B}_{16.7} \mathrm{Si}_{8.3} \mathrm{Ta}_{5}$ bulk glassy alloys exhibits variation tendency similar to that observed in the nano-indentation results (Table 1). The $H_{\mathrm{v}}$ values are smaller than those calculated from the nano-indentation tests. It should be noted that the hardness value is sensitive to the shape and size of indenters and the indentation depth, due to which the change in hardness obtained from different tests is partly attributed to the different indenter geometries, loading modes and indentation depths in the specific experiments [26]. Figure 5 displays the optical images of the Vickers hardness indentations of $\mathrm{Fe}_{70} \mathrm{~B}_{16.7} \mathrm{Si}_{8.3} \mathrm{Ta}_{5}$ and $\mathrm{Fe}_{60-x} \mathrm{Co}_{x-}$ $\mathrm{Ni}_{10} \mathrm{~B}_{16.7} \mathrm{Si}_{8.3} \mathrm{Ta}_{5}(x=0,10$ and 30$)$ bulk glassy alloys. Slip markings (arrows) are seen to form around the Vickers hardness indentation obtained with a rather high load of $500 \mathrm{~g}$. The generation of a number of slip markings and the absence of appreciable cracking indicate that the Fe-based bulk glassy alloys are not extremely brittle [8].

The $B_{\mathrm{s}}$ and $H_{\mathrm{c}}$ of the $\mathrm{Fe}_{70} \mathrm{~B}_{16.7} \mathrm{Si}_{8.3} \mathrm{Ta}_{5}$ and $\mathrm{Fe}_{60-x} \mathrm{Co}_{x-}$ $\mathrm{Ni}_{10} \mathrm{~B}_{16.7} \mathrm{Si}_{8.3} \mathrm{Ta}_{5}(x=0,10,20$ and 30$)$ glass ribbons were determined from their hysteresis loop curves (Fig. 6) and are summarized in Table 1. The Fe-based glassy alloys exhibit a combination of high $B_{\mathrm{s}}$ but low $H_{\mathrm{c}}$, indicating of their good soft magnetic properties. Due to the alloying addition of $\mathrm{Ni}$, the $B_{\mathrm{s}}$ of alloys is first increased from 1.02 to $1.04 \mathrm{~T}$ with

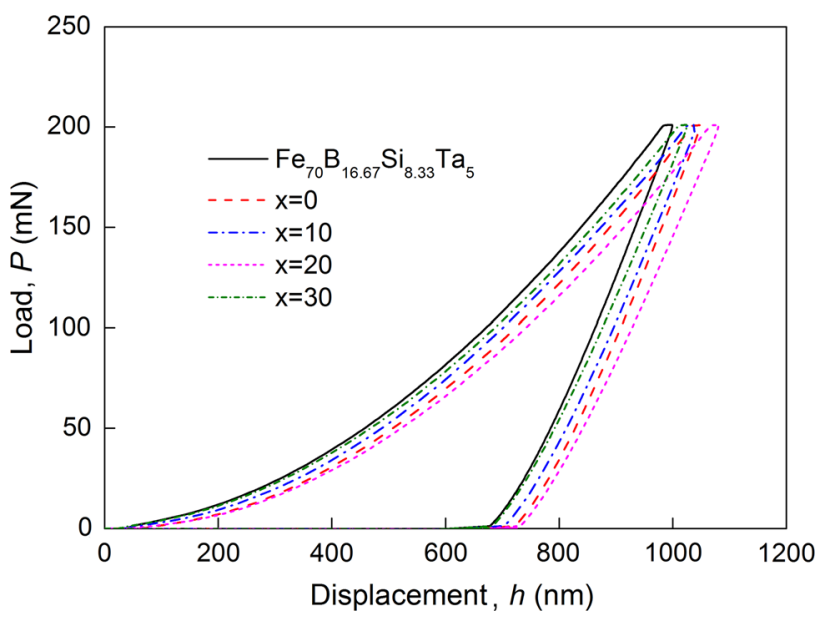

Fig. 4 Average load-displacement $(P-h)$ curves of the $\mathrm{Fe}_{70} \mathrm{~B}_{16.7}$ $\mathrm{Si}_{8.3} \mathrm{Ta}_{5}$ and $\mathrm{Fe}_{60-x} \mathrm{Co}_{x} \mathrm{Ni}_{10} \mathrm{~B}_{16.7} \mathrm{Si}_{8.3} \mathrm{Ta}_{5}(x=0,10,20$ and 30$)$ bulk glassy alloys measured by nano-indentation 

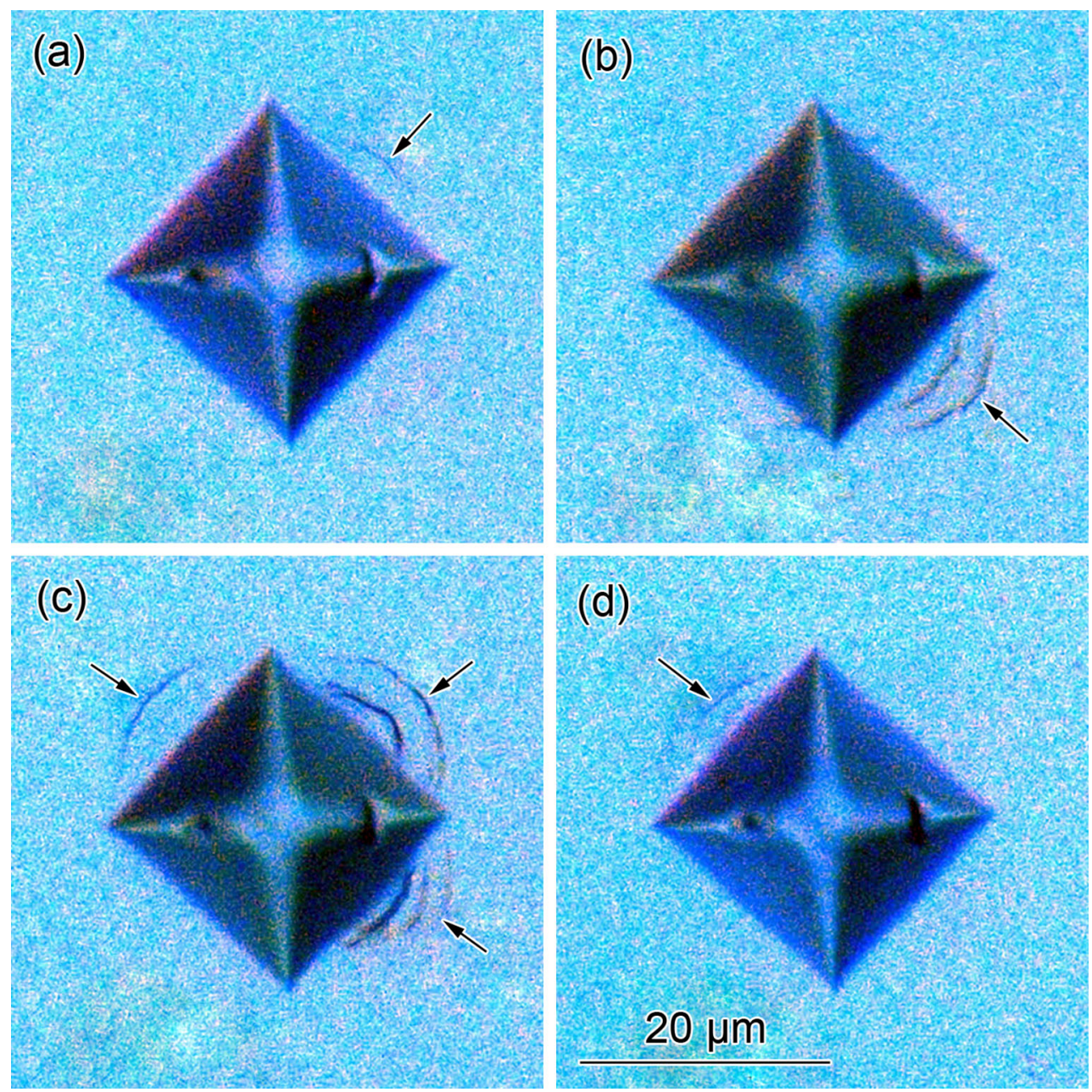

Fig. 5 Optical micrographs of the Vicker's hardness indentation of a $\mathrm{Fe}_{70} \mathrm{~B}_{16.7} \mathrm{Si}_{8.3} \mathrm{Ta}_{5}, \mathbf{b} \mathrm{Fe}_{60} \mathrm{Ni}_{10} \mathrm{~B}_{16.7} \mathrm{Si}_{8.3} \mathrm{Ta}_{5}, \mathbf{c} \mathrm{Fe}_{50} \mathrm{Ni}_{10} \mathrm{Co}_{10} \mathrm{~B}_{16.7} \mathrm{Si}_{8.3} \mathrm{Ta}_{5}$, d $\mathrm{Fe}_{30} \mathrm{Ni}_{10} \mathrm{Co}_{30} \mathrm{~B}_{16.7} \mathrm{Si}_{8.3} \mathrm{Ta}_{5}$ bulk glassy alloys under a $500 \mathrm{~g}$ load

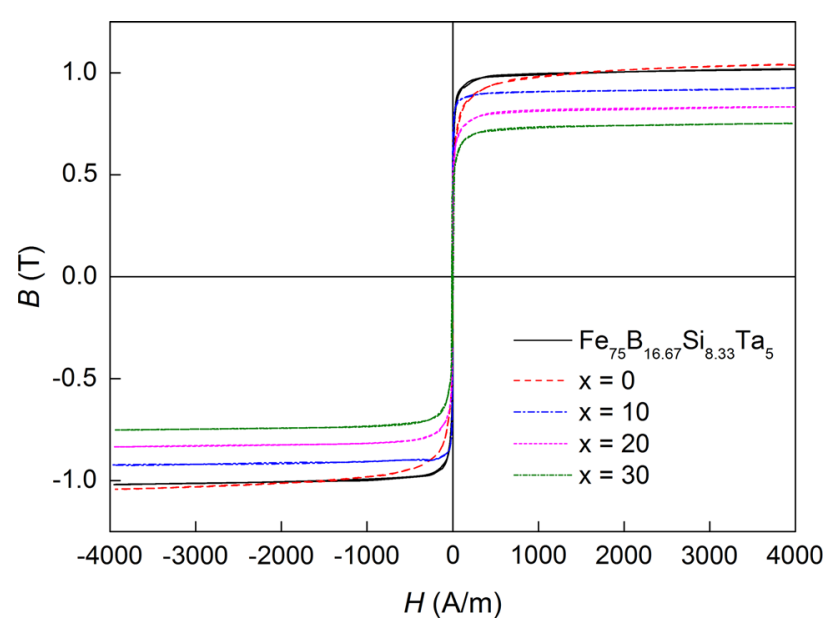

Fig. 6 Hysteresis $B-H$ curves of the $\mathrm{Fe}_{70} \mathrm{~B}_{16.7} \mathrm{Si}_{8.3} \mathrm{Ta}_{5}$ and $\mathrm{Fe}_{60}$ ${ }_{x} \mathrm{Co}_{x} \mathrm{Ni}_{10} \mathrm{~B}_{16.7} \mathrm{Si}_{8.3} \mathrm{Ta}_{5}$ glassy ribbons

increasing $\mathrm{Ni}$ content, and then decreased to $0.75 \mathrm{~T}$ at the composition with 30 at. $\% \mathrm{Co}$. The $\mathrm{Fe}_{70} \mathrm{Ni}_{10} \mathrm{~B}_{16.7} \mathrm{Si}_{8.3} \mathrm{Ta}_{5}$ alloy shows the highest $B_{\mathrm{s}}$ but lowest $H_{\mathrm{c}}$ values in the series of (Fe,
$\mathrm{Ni}, \mathrm{Co})-\mathrm{B}-\mathrm{Si}-\mathrm{Ta}$ alloys. In contrast to the evidently decreased $B_{\mathrm{s}}$ and drastically increased of $H_{\mathrm{c}}$ as brought about by the like atom of $\mathrm{Ni}$, the Co element is found to be not effective in improving the soft magnetic properties of alloys. As for the $B_{\mathrm{s}}$ variation in the Ni and Co alloyed Fe-metalloidtype glassy alloys, the fact that the $B_{\mathrm{s}}$ first increases to a maximum and then decreases with increasing $\mathrm{Ni}$ and $\mathrm{Co}$ content would signal a transition from weak ferromagnetism, i.e., both spin bands are partially filled at the Fermi energy, to strong ferromagnetism, i.e., a completely filled majority-spin band, which is essentially the same as in the other (Fe,Co)based glassy alloys [27, 28].

\section{Conclusions}

The glass-forming ability, mechanical and soft magnetic properties of the $\mathrm{Fe}_{60-x} \mathrm{Co}_{x} \mathrm{Ni}_{10} \mathrm{~B}_{16.7} \mathrm{Si}_{8.3} \mathrm{Ta}_{5}(x=0,10,20$ and 30) glassy alloys with different $\mathrm{Ni}$ and Co contents are summarized as follows: 
1. The alloying additions of $\mathrm{Ni}$ and $\mathrm{Co}$ in the $\mathrm{Fe}_{70} \mathrm{~B}_{16.67-}$ $\mathrm{Si}_{8.33} \mathrm{Ta}_{5}$ alloy result in improved glass-forming ability of the alloys. New bulk glassy alloys, namely $\mathrm{Fe}_{60-x \text { - }}$ $\mathrm{Co}_{x} \mathrm{Ni}_{10} \mathrm{~B}_{16.7} \mathrm{Si}_{8.3} \mathrm{Ta}_{5}(x=10,20$ and 30$)$ with a critical diameter of $1.5 \mathrm{~mm}$ were obtained. Large supercooled liquid spans of $\Delta T_{x} \sim 35-40 \mathrm{~K}$ and a high $T_{\mathrm{rg}} \sim 0.593-0.613$ are found in these bulk glassy alloys. The Young's modulus and the nano-hardness of this new bulk glassy alloy rods are $E \sim 144-178 \mathrm{GPa}$ and $H_{\mathrm{N}} \sim 11.3-12.9 \mathrm{GPa}$, respectively. All glassy ribbons exhibit high $B_{\mathrm{s}} \sim 0.75-1.04 \mathrm{~T}$ but low $H_{\mathrm{c}} \sim 0.2-5.2 \mathrm{~A} / \mathrm{m}$. An appropriate amount of $\mathrm{Ni}$ in these glassy alloys can effectively improve their soft magnetic properties. The $\mathrm{Fe}_{60} \mathrm{Ni}_{10} \mathrm{~B}_{16.7} \mathrm{Si}_{8.3} \mathrm{Ta}_{5}$ glassy ribbon exhibit the highest $B_{\mathrm{s}}(1.04 \mathrm{~T})$ and lowest $H_{\mathrm{c}}$ $(0.2 \mathrm{~A} / \mathrm{m})$ among these alloys.

2. Both the reduced glass transition temperature, $T_{\mathrm{rg}}$, and the enthalpy of supercooled liquid, $\Delta H_{\text {sup }}$, can be used to assess the glass-forming ability of the like-atomtype glassy alloys.

3. (Fe,Co,Ni)-B-Si-Ta ferromagnetic bulk glassy alloys are promising materials for both structural and functional applications due to the combination of high glass-forming ability, ultrahigh mechanical strength and good soft magnetic properties.

Acknowledgements This work was supported by the National Natural Science Foundation of China (Nos. 51671045 and 51601073), the State Key Laboratory of Solidification Processing in NWPU (No. SKLSP201607) and the Start-up Cost in Jiangsu University of Science and Technology (No. 1062931608).

\section{References}

[1] T. Egami, Rep. Prog. Phys. 47, 1605 (1984)

[2] R. Hasegawa, J. Magn. Magn. Mater. 100, 1 (1991)

[3] M.E. McHenry, M.A. Willard, D.E. Laughlin, Prog. Mater Sci. 44, 300 (1999)
[4] G.E. Fish, Proc. IEEE 78, 947 (1990)

[5] A. Inoue, Y. Shinohara, J.S. Gook, Mater. Trans., JIM 36, 1427 (1995)

[6] C. Suryanarayana, A. Inoue, Int. Mater. Rev. 58, 131 (2013)

[7] A. Inoue, B.L. Shen, Mater. Trans. 43, 766 (2002)

[8] Y.X. Geng, Y.M. Wang, J.B. Qiang, G.F. Zhang, C. Dong, O. Tegus, J.Z. Sun, Intermetallics 67, 138 (2015)

[9] Y.X. Geng, Y.M. Wang, Z.R. Wang, H.B. Wang, J.B. Qiang, C. Dong, O. Tegus, Mater. Des. 106, 69 (2016)

[10] Y.X. Geng, K.M. Han, Y.M. Wang, J.B. Qiang, Q. Wang, C. Dong, G.F. Zhang, O. Tegus, P. Häussler, Acta Metall. Sin. 51, 1017-1024 (2015). (in Chinese)

[11] S. Báez, I. Betancourt, I.A. Figueroa, Acta Metall. Sin. 23, 401 (2010). (Engl. Lett)

[12] A. Takeuchi, A. Inoue, Mater. Trans. 46, 2817 (2005)

[13] R. Li, S. Kumar, M. Stoica, S. Roth, J. Eckert, J. Phys. D Appl. Phys. 42, 085006 (2009)

[14] J. Torrens-Serra, P. Bruna, M. Stoica, S. Roth, J. Eckert, J. NonCryst, Solids 367, 30 (2013)

[15] C. Dong, Q. Wang, J.B. Qiang, Y.M. Wang, N. Jiang, G. Han, Y.H. Li, J. Wu, J.H. Xia, J. Phys. D Appl. Phys. 40, R273 (2007)

[16] W.C. Oliver, G.M. Pharr, J. Mater. Res. 19, 3 (2004)

[17] B. Shen, A. Inoue, C. Chang, Appl. Phys. Lett. 85, 4911 (2004)

[18] T. Bitoh, A. Makino, A. Inoue, A.L. Greer, Appl. Phys. Lett. 88, 182510 (2006)

[19] C.T. Chang, B.L. Shen, A. Inou, Appl. Phys. Lett. 88, 11901 (2006)

[20] B.L. Shen, C.T. Chang, A. Inoue, Intermetallics 15, 9 (2007)

[21] H.X. Li, S.L. Wang, S. Yi, Z.B. Jiao, Y. Wu, Z.P. Lu, J. Magn. Magn. Mater. 321, 2833 (2009)

[22] H.X. Li, H.Y. Jung, S. Yi, J. Magn. Magn. Mater. 320, 241 (2008)

[23] H. Ling, Q. Li, H. Li, J. Zhang, Y. Dong, C. Chang, Y. Seonghoon, J. Appl. Phys. 115, 204901 (2014)

[24] F.X. Qin, Y. Zhou, C. Ji, Z.H. Dan, G.Q. Xie, S. Yang, Acta Metall. Sin. 29, 1101 (2016). (Engl. Lett)

[25] J.J. Si, T. Wang, Y.D. Wu, Y.H. Cai, X.H. Chen, W.Y. Wang, Z.K. Liu, D. Hui, Appl. Phys. Lett. 106, 251905 (2015)

[26] H.W. Zhang, G. Subhash, L.J. Kecskes, R.J. Dowding, Scr. Mater. 49, 447 (2003)

[27] S. Bhattacharya, E.A. Lass, S.J. Poon, G.J. Shiflet, M. Rawlings, M. Daniil, M.A. Willard, J. Appl. Phys. 111, 63906 (2012)

[28] K. Amiya, A. Urata, N. Nishiyama, A. Inoue, J. Appl. Phys. 97, 10F913 (2005) 